\title{
MODEL PEMBELAJARAN KOOPERATIF LEARNING TIPE JIGSAW DALAM MENINGKATKAN MOTIVASI BELAJAR SEJARAH
}

\author{
Naovan Noor Sadiq \\ Program Studi Pendidikan Sejarah FKIP Universitas Lambung Mangkurat
}

Banjarmasin

Email: 1710111210020@mhs.ulm.ac.id

\begin{abstract}
Abstrak: dalam pembelajaran di kelas diperlukan adanya sebuah inovasi, tidak terkecuali dalam pembelajaran sejarah. Keaktifan siswa dalam pembelajaran sangat bergantung kepada gurunya. Oleh karena itu, diperlukan guru yang kreatif, imajinatif serta inovatif agar dapat mencapai keberhasilan dalam kelasnya. suasana kelas harus direncanakan sedemikian rupa sesuai dengan menggunakan model pembelajaran yang sesuai, sama halnya dengan model pembelajaran kooperatif learning tipe jigsaw di dalam kelas sejarah dapat meningkatkan motivasi belajara pada siswa.

Model pembelajaran kooperatif learning tipe jigsaw diharapkan dapat memberikan inovasi dan variasi dalam pembelajaran agar dapat meningkatkan motivasi dan minat belajar siswa terutama dalam pembelajaran sejarah.
\end{abstract}

Kata kunci: Kooperatif learning tipe jigsaw, motivasi belajar

\section{PENDAHULUAN}

Dalam dunia pendidikan guru memiliki peran penting dalam proses pembelajaran. Kemampuan guru dalam melaksanakan kegiatan belajar mengajar merupakan faktor penting untuk mencapai tujuan pendidikan. Secara umum guru bertugas mengembangkan kemampuan siswa secara optimal dalam asfek kognitif, afektif, dan psikomotorik. Dalam menjalankan tugas dan tanggung jawabnya, seorang guru perlu menjadi pribadi yang mulia, memiliki sikap yang membuat para siswa merasa nyaman dengan memberikan pengajaran dengan untaian kata-kata sarat yang bermakna mendidik (Melisa Prawitasari,2015: 146).

Dalam pembelajaran sejarah di sekolah guru dituntut untuk dapat melatih cara berpikir seorang siswa. Seorang guru merupakan sosok utama dalam suatu pendidikan yang dimana tugas guru adalah mendidik, mengadakan pengajaran serta memberikan penilaian. Namun, untuk mencapai keberhasilan dalam sebuah pembelajaran diperlukan motivasi belajar dari siswa. Untuk meningkatkan motivasi belajar siswa guru perlu memiliki keterampilan dalam menggunakan ataupun mengembangkan model pembelajaran yang kreatif, efektif dan menyenangkan. Dikarenakan model dan metode pembelajaran yang digunakan guru kurang melibatkan partisipasi dari para siswa. Banyak siswa yang beranggapan bahwa pembelajaran sejarah adalah pembelajaran yang membosankan.

Pendidikan dalam fakta sejarah telah membawa banyak perubahan, bukan hanya perubahan pada diri individu terdidik akan tetapi juga perubahan bangsa dan negara. Sebagai gambaran bisa kita lihat bagaimana lahirnya identitas kebangsaan negara-negara di Asia yang 
sangat dipengaruhi oleh insan-insan terdidik (Heri Susanto, 2016: 309). Yang berarti dalam pembelajaran sejarah diperlukan penanaman nilai-nilai nasionalisme dan penggunaan model pembelajaran juga perlu mengimplementasikan nilai-nilai nsionalisme ini untuk mencapai keberhasilan dalam pembelajaran sejarah di kelas.

Dampak dari dominannya guru melaksanakan pembelajaran dengan menggunakan pembelajaran konvesional juga mempengaruhi motivasi belajar siswa. motivasi belajar merupakan hal yang sangat penting dalam pembelajaran untuk mempermudah siswa dalam mencapai tujuan pembelajaran yang telah ditetapkan guru sehingga pada akhirnya prestasi belajar siswa pun akan meningkat (M.Zainal Mustamin, 2016: 67).

Model pembelajaran kooperatif merupakan salah satu model pembelajaran yang mendukung pembelajaran kontekstual. Pembelajaran kooperatif adalah salah satu bentuk pembelajaran yang berdasarkan paham konstruktivisme. Pembelajaran kooperatif ini merupakan strategi belajar dengan sejumlah siswa sebagai anggota kelompok kecil yang tingkat kemampuannya berbeda. Dalam menyelesaikan tugas kelompoknya, setiap siswa anggota kelompok harus saling bekerjasama dan saling membantu untuk memahami materi pelajaran (I Ketut Tastra, dkk, 2013: 3)

Hamzah (dalam I Ketut Tastra, dkk, 2013: 4) menjelaskan bahwa "Jigsaw adalah salah satu pendekatan dalam pembelajaran kooperatif dimana dalam penerapannya siswa dibentuk dalam kelompok-kelompok, tiap kelompok terdiri atas tim ahli sesuai dengan pertanyaan yang disiapkan guru maksimal lima pertanyaan sesuai dengan jumlah tim ahli”.

Maka jika dikaitkan dengan pembelajaran sejarah, maka dengan model pembelajaran kooperatif tipe jigsaw diharapkan dapat meningkatkan motivasi belajar siswa serta mampu meningkatkan hasil belajar siswa dan mengubah pandangan bahwa pelajaran sejarah dalah membosankan dengan menggunakan cara dan model yang bervariasi agar menjadi pembelajaran yang menyenangkan.

\section{MODEL PEMBELAJARAN KOOPERATIF LEARNING TIPE JIGSAW}

Dikutip dari Heri Susanto (2015:34) bahwa Pembelajaran adalah dampak dari Berpikir. Retensi, pemahaman, dan penggunaan aktif pengetahuan bisa tercipta hanya dengan pengalaman pembelajaran dimana murid berpikir tentang, dan berpikir dengan, apa yang mereka pelajari (Perkins dalam Eggen \& Kaucak, 2012:110).

Dikutip dari Ummi Ryosyidah (2016: 117) menurut Lie (dalam Rusman, 2013) menyatakan bahwa pengertian model pembelajaran kooperatif tipe Jigsaw adalah model belajar kooperatif dengan cara siswa belajar dalam kelompok kecil yang terdiri dari 4 - 6 siswa secara heterogen, memberikan kesempatan siswa dapat bekerja sama, saling ketergantungan positif di antara siswa dan siswa mampu bertanggung jawab secara mandiri.

Amri dan Ahmadi (dalam Ahmad Syarifuddin, 2011: 211-212) system pengajaran cooperative learning dapat didefinisikan sebagai system kerja atau belajar kelompok yang terstruktur dan cooperative learning adalah suatu strategi belajar mengajar yang menekankan 
pada sikap atau perilaku bersama dalam bekerja yang teratur kelompok, yang terdiri dua orang atau lebih

Jadi dalam model pembelajaran kooperatif tipe jigsaw ada kelompok asal dan kelompok ahli dimana kelompok asal merupakan gabungan dari beberapa ahli dan Kelompok ahli yaitu kelompok siswa yang terdiri dari anggota kelompok asal yang berbeda yang ditugaskan untuk mempelajari dan mendalami topik tertentu dan menyelesaikan tugas-tugas yang berhubungan dengan topiknya untuk kemudian dijelaskan kepada anggota kelompok asal. Dalam model pembelajaran ini siswa memiliki banyak kesempatan untuk mengemukakan pendapat, dan mengolah informasi yang didapat dan meningkatkan keterampilan berkomunikasi. Semua siswa berpartisipasi dalam kegiatan pembelajaran dan memiliki tanggung jawab atas keberhasilan kelompok asalnya.

\section{MOTIVASI BELAJAR}

Soemanto (dalam Keke T. Aritonang, 2008: 13) menyatakan bahwa belajar adalah suatu proses dan bukan suatu hasil. Oleh karena itu belajar berlangsung secara aktif dan integratif dengan menggunakan berbagai bentuk perbuatan untuk mencapai suatu tujuan.

Sardiman, Riduwan (dalam Keke T. Aritonang, 2008: 14) mengatakan bahwa motivasi belajar adalah keseluruhan daya penggerak di dalam diri siswa yang menimbulkan kegiatan belajar, yang menjamin kelangsungan dari kegiatan belajar dan memberi arah pada kegiatan belajar, sehingga tujuan yang dikehendaki oleh subjek belajar itu dapat tercapai. Dan juga bahwa motivasi merupakan suatu daya atau kekuatan yang timbul dari dalam diri siswa untuk memberikan kesiapan agar tujuan yang telah ditetapkan tercapai. Sedangkan belajar merupakan suatu proses yang dilakukan siswa untuk memperoleh perubahaan tingkah laku yang lebih baik dan sebelumnya sebagai hasil pengalaman siswa dalam berinteraksi dengan lingkungannya. Motivasi belajar siswa meliputi dimensi:

1. Ketekunan dalam belajar, yaitu kehadiran di Sekolah, mengikuti PBM di kelas dan belajar di rumah.

2. Ulet dalam menghadapi kesulitan, yaitu sikap terhadap kesulitan dan usaha mengatasi kesulitan.

3. Minat dan ketajaman perhatian dalam belajar, yaitu kebiasaan dalam mengikuti pelajaran dan semangat dalam mengikuti PBM.

4. Berprestasi dalam belajar, yaitu keinginan untuk berprestasi.

5. Mandiri dalam belajar, yaitu Penyelesaian tugas/PR dan menggunakan kesempatan di luar jam pelajaran.

Motivasi belajar ini dapat membuat siswa lebih semangat, rajin dan tekun dalam mengikuti kegiatan pembelajaran, terlebih lagi jika kita sebagai seorang guru dapat menjadi inovatif dalam menggunakan media dan model pembelajaran sehingga suasana yang tercipta di kelas dapat merangsang peningkatan minat dan motivasi belajar siswa. 


\section{MODEL KOOPERATIF JIGSAW DALAM MENINGKATKAN MOTIVASI BELAJAR SEJARAH}

Pembelajaran sejarah sering diidentikkan dengan pembelajaran yang bersifat hapalan, tekstual dan terbatas pada aspek kognitif tingkat rendah. Anggapan ini bukan tanpa alasan, pada kenyataannya pembelajaran yang dilakukan memang cenderung pada ketiga hal tersebut (Heri Susanto, 2014: 394).

Jika tujuan pembelajaran sejarah adalah siswa memahami dan menghayati nilai-nilai yang terkandung dalam setiap peristiwa sejarah, maka desain pembelajaran yang dibuat harus mampu mengungkapkan nilai-nilai tersebut sehingga mudah dipahami oleh peserta didik. Nilai-nilai persatuan, kerjasama, kejuangan, kegigihan dan empati, tidak akan didapat siswa melalui pembelajaran sejarah yang hanya bersifak kronikel dan hanya mengutamakan hapalan (Heri Susanto, 2014: 31).

Hal inilah yang menurut saya dengan digunakannya model pembelajaran kooperatif learning tipe jigsaw dapat meningkatkan kemampuan siswa bukan hanya di ranah kognitif tapi juga dalam ranah afektif dan psikomotorik, dimana model ini dapat meningkatkan kerjasama, rasa tanggung jawab dan kemampuan berkomunikasi yang secara berurutan dapat meningkatkan minat belajar siswa terlebih lagi pada pembelajaran sejarah

\section{PENUTUP}

Model pembelajaran kooperatif learning tipe jigsaw adalah model pembelarajan yang membagi siswa kedalam kelompok-kelompok dimana terdapat kelompok asal dan kelompok ahli, pertama siswa dibagi dalam kelompok asal yang masing-masing anggotanya memiliki topik yang berbeda yang kemudian dibagi kembali kedalam kelompok ahli yang membahas topik yang sama, kemudian siswa membahas topik itu di dalam kelompok ahli dan kemudian kembali kepada kelompok asal dan menyampaikan informasi tentang topik yang tadi dibahas di kelompok ahli.

Model pembelajaran ini menuntut siswa agar memiliki rasa tanggung jawab karena keberhasilan kelompoknya ditetukan oleh usaha mereka selama kegiatan pembelajaran, rasa kerjasama dalam kelompok asal dan ahli untuk mendapatkan hasil yang diinginkan, dengan menggunakan model pembelajaran ini seluruh siswa dituntut untuk berpartisipasi dalam kegiatan pembelajaran sehingga dapat merangsang motivasi belajar.

\section{DAFTAR PUSTAKA}

Buku

Susanto, Heri. 2014. Seputar Pembelajaran Sejarah (Isu, Gagasan dan Strategi

Pembelajaran) (Isu, Gagasan dan Strategi Pembelajaran). Aswaja Pressindo. Banjarmasin.

Jurnal

I Ketut Tastra, A. A. I N. Marhaeni, I Wayan Lasmawan (2013). Pengaruh Penggunaan Model Pembelajaran Kooperatif Tipe Jigsaw Terhadap Hasil Belajar Menulis 
Ditinjau dari Motivasi Berprestasi Siswa Kelas VII SMP Negeri 4 Mendoyo. eJournal Program Pascasarjana Universitas Pendidikan Ganesha Jurusan Pendidikan Dasar (Volume 3 Tahun 2013)

Keke T. Aritonang (2008). Minat dan Motivasi dalam Meningkatkan Hasil Belajar Siswa. Jurnal Pendidikan Penabur No.10

Mustamin, M.Zainal (2016). Pengaruh Penggunaan Model Kooperatif Learning Tipe Jigsaw Terhadap Hasil Belajar Ips Di Tinjau Dari Motivasi Berpretasi. Jurnal Teknologi Pendidikan Volume 1 Nomor 2

Prawitasari, Melisa (2015). Metode Pembelajaran Hypnoteaching Melalui Mind Mapping dalam Pembelajaran Sejarah (Studi Pada Siswa Kelas XI IPS SMA PGRI 6 Banjarmasin). Seminar Nasional.

Ryosidah, Ummi (2016). Pengaruh Model Pembelajaran Kooperatif Tipe Jigsaw Terhadap Hasil Belajar Matematika Siswa Kelas Viii Smp Negeri 6 Metro. Jurnal SAP Vol. 1 No. 2

Susanto, Heri (2014). Kemampuan Berpikir Kritis dalam Pedagogi Sejarah Sebagai Upaya Membangun Karakter Peserta Didik. In: Building Nation Character Through Education: Proceeding International Seminar on Character Education.

Susanto, Heri (2015). Menghadirkan kelas Konstruktivis dalam Melatih Kemampuan berpikir Historis melalui model latihan Penelitian. Seminar Nasional.

Susanto, Heri (2016) Pendidikan dan Kesadaran Nasionalisme. In: Developing Education Based on Nationalism Values: The Proceeding of International Seminar Building Education Based on Nationalism Values.

Syarifuddin, Ahmad (2011). Model Pembelajaran Cooperative Learning Tipe Jigsaw dalam Pembelajaran. Ta'dib, vol. Xvi, no. 02 